\title{
Delight in Painted Companions: Shaping the Soul from Birth in Early Modern Italy
}

\author{
Maya Corry
}

Just over ten years ago, a curious sixteenth-century picture was sold by Christie's in New York for the relatively small sum of 3840 dollars, a little under its lower estimate [Fig. 13.1]. It is not the sort of work that much troubles art historians. We do not know who painted it, and it is not of high quality. The anatomy of the figures is chunky and clumsy, they are unconvincingly superimposed onto the landscape, and the handling of light and shade is crude. A note accompanying the painting's sale stated that 'The present composition is based on The Virgin of the Rocks by Leonardo in the Musée du Louvre, Paris. The figure of the Virgin has been replaced here by the Christ Child and another male child has been introduced to the composition'. ${ }^{1}$

Cheap, small-scale religious works on panel such as this were produced in enormous numbers throughout the sixteenth century. The dimensions of this particular picture $(42.5 \times 35.6 \mathrm{~cm})$ are typical of those made for domestic contexts. For the first time, ordinary homes around Italy were adorned with paintings - commissioned from artists, bought directly from workshops, or purchased from mercantile middle-men. Their primary function was to invoke divine blessings and protection on the home, and provide a focus for the prayers of members of the household. Why then, in this case, has the Madonna been removed from the composition? Faith in her intercessory power and maternal love for mankind meant that she was by far and away the most popular subject for domestic works of art. Yet here she has been erased, and whilst the Christ Child is more or less as he appears in the Virgin of the Rocks, the figure of John the Baptist has been transformed into a kneeling toddler in a diaphanous robe, and the saint now appears as the newly introduced standing child. The composition as a whole has been dramatically contracted and, with the addition of the third child and loss of the Virgin and the angel, its meaning transformed.

1 http://www.christies.com/lotfinder/Lot/manner-of-leonardo-da-vinci-the-christ-4514030 -details.aspx.

(C) MAYA CORRY, 2019 | DOI:10.1163/9789004375871_015

This is an open access chapter distributed under the terms of the prevailing CC-BY-NC-ND License at the time of publication. 


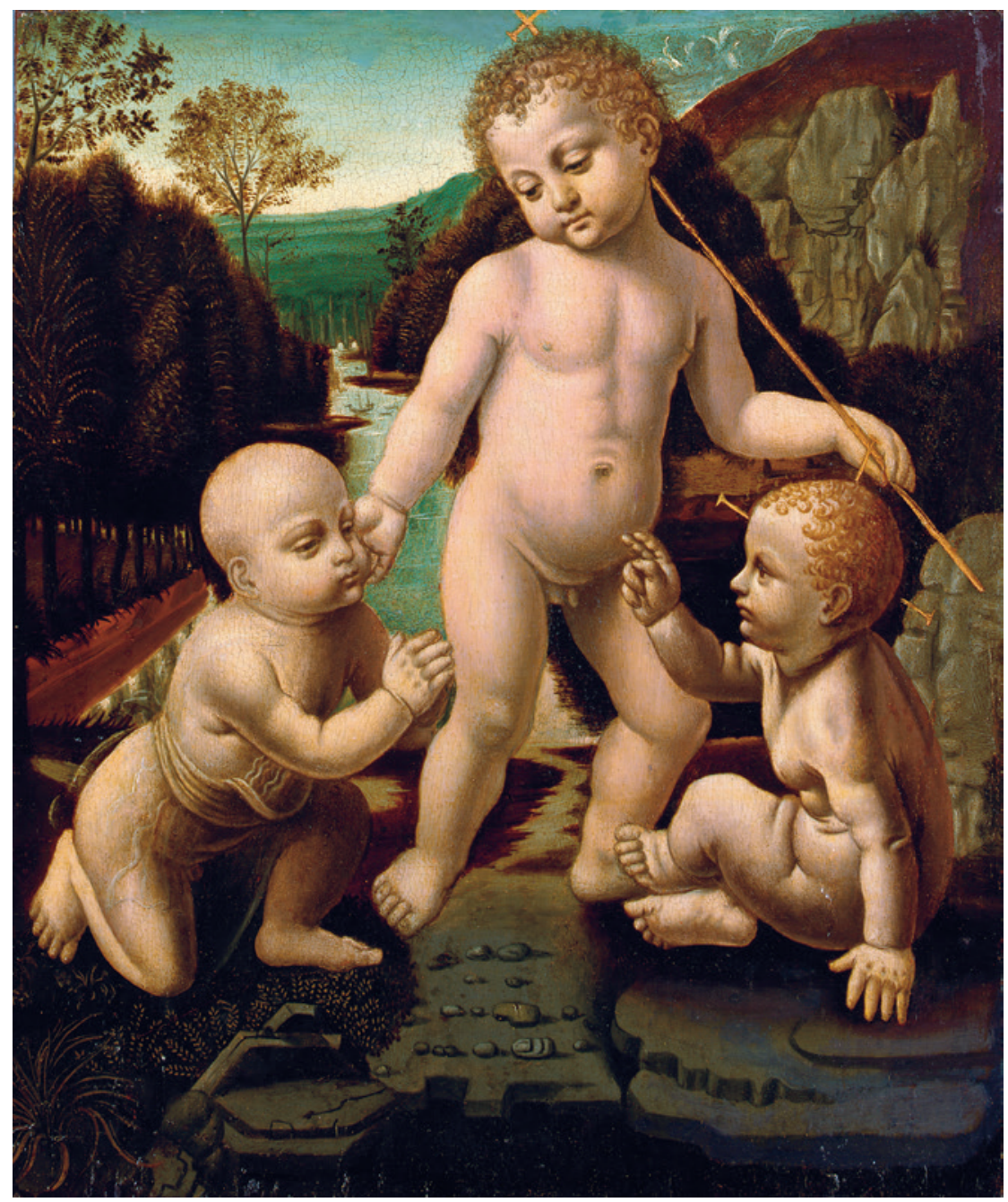

FIGURE 13.1 "The Christ Child with the infant Saint John the Baptist with an unidentified male child", sixteenth century. $42.5 \times 35.6 \mathrm{~cm}$, private collection

(C) CHRISTIE'S IMAGES / BRIDGEMAN IMAGES

Who might have commissioned this painting, which explicitly borrows from the Virgin of the Rocks only to reconfigure the relationships of the figures in this strange way, and why? Despite its questionable artistic quality (or perhaps because of it), this odd little painting provides a window into the concerns and beliefs of those lower down the social scale - those who are still rarely the subject of art historical investigation - who could not afford to commission a 
work from an acknowledged master, but were able to muster up the funds for a small painting by a less skilled painter. ${ }^{2}$

Well into the sixteenth century it is commonplace to find echoes of Leonardo's work in cheap Lombard paintings made for domestic contexts. ${ }^{3}$ Traditionally, these have been categorised by art historians as 'Leonardesque'. This nomenclature points to some unexamined assumptions about the appeal of such works, and their primary reason for being. It is possible that either the maker or the commissioner of this image knew of and admired Leonardo's Virgin of the Rocks altarpiece. But it is equally probable that an explicit link with Leonardo was neither the motivation for the panel's creation (as the changes to the composition suggest), nor the primary way in which its owner would have conceptualised it. Affordable 'Leonardesque' pictures produced for non-elite consumers across Lombardy (often years after Leonardo had resided in the region) just as likely carried overtones of good taste, beauty, urbane sophistication, devotional efficacy or simply a 'Milanese look', than were universally acknowledged to be connected with the Florentine master.

In order to speculate meaningfully about the original significance of this painting, and others like it, it is necessary to move beyond a focus on Leonardo to take account of more personal, familial and domestic concerns - the kinds of beliefs and social norms that made ownership of images like this desirable, and perhaps for some, imperative. It will be argued here that widely held contemporary beliefs relating to childhood on the one hand, and images on the other, harmonised in culturally significant ways. As a result, artworks such as this could be uniquely efficacious weapons in the arsenals of those seeking to raise spiritually pure children in early modern Italy.

As many of the essays in this volume indicate, neither domestic space nor domestic experience in Renaissance Italy were securely delineated; rather they were shaped by continuous interactions with other spheres: communal, parochial, civic, institutional, devotional, intellectual, and so on. Yet it is also the case that contemporaries characterised certain experiences and activities

2 When in 1515 Bernardo Zenale was required to value the paintings in his family's possession, he rated the small, devotional works as being worth from less than one lira up to six lire. This range is typical, and those at the cheaper end of this scale would have been within the means of anyone with steady employment. On Zenale see Shell J., Pittori in bottega: Milano nel Rinascimento (Turin: 1995) 171.

3 Leonardo lived and worked in Milan from 1482 to 1499 , and 1506 to 1513. 
as inherently 'domestic' in nature: birth, for instance, and childrearing. ${ }^{4}$ The age most closely associated with domesticity was infanzia, which was generally thought of as lasting from birth to two or four years, or until speech commenced, according to Matteo Palmieri in his Della vita civile. ${ }^{5}$ Other than for the indigent and abandoned, the earliest years of life were spent within the home, whether of parents, wet-nurses or kin. ${ }^{6}$ Indeed, later ages were defined in contemporary thought by growing distance from the domestic sphere, when children would 'begin to throw off the maternal yoke and to go out among others.'

During this crucial first stage of life attentive and responsible parents had to commence the work of forming their charges into good Catholics. ${ }^{8}$ This was a critical endeavour, as commonplace beliefs about the childish body and soul, as well as high rates of infant mortality, affirmed. An individual's character was thought to be formed largely within the first few years of life: if the

4 There is a large literature on childhood and the family in the early modern era. See for instance Cavallo S. - Evangelisti S. (eds.), A Cultural History of Childhood and Family: The Early Modern Age (Oxford: 2000) and bibliography. The schema of the ages of man meant that life was thought of as a series of relatively distinct stages. While the realities of life for many children did not adhere to this schema, it did inform social structures and norms in a number of significant ways: apprenticeships, political office, marriage, inheritance and other key transitions were only undertaken at the attainment of a certain age. See Burrow J.A., The Ages of Man: A Study in Medieval Writing and Thought (New York: 1986); Sears E., The Ages of Man: Medieval Interpretations of the Life Cycle (Princeton: 1986).

5 Palmieri Matteo, Libro della vita civile (Florence, Filippo Giunta: 1529) 20. The ages of man were generally divided into seven, but for those authors who specified fewer ages infancy was said to last until the age of seven.

6 On those unlucky children who were not raised within the family home see Terpstra N., AbandonedChildrenof the ItalianRenaissance:Orphan Care in FlorenceandBologna (Baltimore: 2005); Niccoli O., Il seme della violenza: Putti, fanciulli e mammoli nell'Italia tra Cinque e Seicento (Rome-Bari: 1995). Even those children who were institutionalised were sometimes put out to foster care in their earliest years. On wet-nursing see Klapisch-Zuber C., "Blood Parents and Milk Parents: Wet Nursing in Florence, 1300-1530", in Women, Family, and Ritual in Renaissance Italy, trans. L. Cochrane (Chicago: 1985) 132-164.

7 Dominici Giovanni, Regola del governo di cura familiare, ed. D. Salvi (Florence: 1860) 148. For many children apprenticeships or service were formally entered into at the age of 12 or thereabouts (although those belonging to families from the lower orders often commenced work of some kind at an earlier age).

8 Although most advice literature was aimed at parents, other adults could also play significant roles, including kin, godparents, tutors, employers and teachers (those who taught in the Schools of Christian Doctrine were lay volunteers). Advice addressed to parents was equally pertinent to these other adults. On godparents see Alfani G., Fathers and Godfathers: Spiritual Kinship in Early-Modern Italy (Aldershot: 2009). On teachers and tutors see Grendler P.F., Schooling in Renaissance Italy: Literacy and Learning, 1300-160o (Baltimore: 1989); Black R., Humanism and Education in Medieval and Renaissance Italy: Tradition and Innovation in Latin Schools from the Twelfth to the Fifteenth Century (Cambridge: 2001). 
fundamentals of a pious nature were not established at this point then they would never be. Drawing on Seneca, Plutarch and Aristotle, in 1403 the humanist Pier Paolo Vergerio stated in arguably the most influential humanist work on education: 'In youth [...] the foundations for living well are to be laid, and the mind must be trained to virtue while it is young and impressionable, for the mind will preserve throughout life the impressions it takes on now'. Compounding this, some authorities held that children had a natural propensity for $\sin .{ }^{10}$ The health of the community - in economic, political and even medical terms, as well as religious ones - depended on the piety of its members, so a heavy weight of social expectation fell on adults with children in their care.

How did those who endeavoured to tend to their charges' souls respond? What avenues were open to those who wished to shape the youngest members of the household into pious citizens? Babies and toddlers were not often brought to church, and those who attended one of the Schools of Christian Doctrine that sprang up across Italy throughout the sixteenth century did not begin their education until aged between four and six. ${ }^{11}$ Anxious parents could seek help in navigating their responsibilities from a wealth of publications on the household, family and education which all offered advice on childrearing. ${ }^{12}$ These texts consistently highlighted the importance of religious instruction

Vergerio Pier Paolo, De ingenuis moribus ac liberalibus studiis liber (Milan, Filippo da Lavagna: 1474). Translated in Kallendorf C. (ed. and trans.), Humanist Educational Treatises (Cambridge, Mass. - London: 2002) 2. Hereafter 'Vergerio'. This work exists in more than 300 manuscripts and was printed in 40 editions.

10 This notion drew on beliefs expressed in Augustine's Confessions, book 1, ch. 7 . Contemporary interest in childhood morality and awareness that this was not always ideally evident is illustrated by Annibale Carracci's Two Children Teasing a Cat, Metropolitan Museum of Art, inv. 1994.142, which may illustrate a contemporary aphorism. On children's proclivity for violence and contemporary concern over this see Niccoli, Il seme della violenza. The belief that children might be inclined to sin conflicted with another current position: that in their innocence the very young were close to God.

11 The first of these schools was founded in Milan in 1536, and later in the century a significant number of children across Italy attended them. This did not, of course, absolve parents of their responsibilities (most obviously in the years before a child was old enough to attend, and not least because the schools were only open for at most 85 days a year). See Grendler P.F., "The Schools of Christian Doctrine in Sixteenth-Century Italy", Church History 53, 3 (1984) 319-331.

12 On this large body of texts, which were aimed at a wide audience, see Frigo D., Il padre di famiglia: governo della casa e governo civile nella tradizione dell"economica" tra Cinque e Seicento (Rome: 1985), and Zarri G. (ed.), Donna, disciplina, creanza cristiana dal XV al XVII secolo: studi e testi a stampa (Rome: 1996), and bibliographies. 
within the home..$^{13}$ There was consensus amongst early modern authorities that parents ought to teach their children how to kneel, make the sign of the cross, and say the Our Father, the Hail Mary and other key religious passages. Historians have rightly emphasised the significance of devotional literature to education: for those of a certain social level letters and reading were taught via primers containing religious material, and adults were expected to read aloud to children from appropriate spiritual texts. ${ }^{14}$ As they grew, boys in particular were encouraged to take on more 'adult' acts, such as charitable giving. ${ }^{15}$ However, less attention has been paid to the significance of works of art in shaping the souls of the youngest members of the household.

\section{The Impressionable Youth}

How did contemporaries conceive of infancy - the first 'age' of man? 'This age is like soft wax, and takes whatever impression is put on it' expounded the Dominican cardinal Giovanni Dominici in his 1403 Regola del governo di cura familiare. ${ }^{16}$ In asserting that youthful matter was especially malleable

13 There is ample evidence that parents followed such advice, see for instance Haas L., The Renaissance Man and His Children: Childbirth and Early Childhood in Florence, 1300-1600 (New York: 1998) 137; Chambers D. - Pullan B. (eds.), Venice: A Documentary History $1450-$ 1630 (Toronto: 2001) 267. In general, mothers were perceived to be responsible for teaching the bodily aspects of devotion, such as how to kneel and the correct posture for prayer. Literate mothers were also expected to teach children their letters, see for example Valier Agostino, Instituzione d'ogni stato lodevole delle donne cristiane, ed. F. Lucioli (Cambridge: 2015). However, the ultimate responsibility for overseeing religious education belonged to fathers, who were enjoined to read regularly from appropriate texts to all members of the household, see for example Tommasi Francesco, Reggimento del padre difamiglia (Florence, Giorgio Marescotti: 1580); Spoleto Cherubino, Regola della vita matrimoniale (Florence, Nicolaus Laurentii: 1477). Over the early modern period there were some shifts in practice, notably the introduction of more thorough religious schooling for children in the wake of the Catholic Reformation (see note 12). However, these basic principles remained unchanged. They were communicated to the laity in treatises (see note 13) but also via preaching, see Delcorno C., "Maestri di preghiera per la pietà personale e di famiglia", Quaderni di storia religiosa 8 (2001) 117-146.

14 For historical discussion of such aspects of religious education see Niccoli O., "Bambini in preghiera nell'Italia fra tardo medioevo e età tridentina", Quaderni di storia religiosa 8 , (2001) 273-299; Evangelisti S., "Faith and Religion", in Cavallo - Evangelisti, A cultural history of childhood $153^{-170 .}$

15 See Chambers - Pullan, Venice 267.

16 Dominici, Regola 137. Dominici's text was written ca. 1400 to provide advice for the Florentine patrician Bartolommea degli Alberti, who had the care of her four children. 
and receptive to outside influence Dominici was echoing Aristotle, Plato and numerous other authorities. In De memoria Aristotle had also employed the metaphor of a seal's imprint in wax to explain how, when they were received into the body with sufficient force, sense impressions (species) left imprints of themselves (phantasmata) which would cause corporeal and spiritual transformation.

Early modern theologians, physicians, preachers and pedagogues all subscribed to this model. ${ }^{17}$ Quoting Virgil, Vergerio explained that it was necessary to commence instruction 'while young minds are malleable, while they are young enough to change.18 Similarly, Aeneas Silvius Piccolomini (later Pope Pius II) asserted in his De liberorum educatione of 1450 that 'whatever habits a child's body forms it wants to preserve subsequently' ${ }^{19}$ Humanist pedagogues expected that parents would be sensitive to these aspects of a youth's matter and nature, for it was acknowledged that 'We follow seamlessly as adults the habits we have formed as children, and boys willingly let themselves be shaped by the desires of the parents who have given them birth and brought them up. ${ }^{20}$

There was general agreement that efforts to shape a child ought to commence from birth. Vergerio declared that it was 'fitting' to consider how to incur virtue and respect for the divine 'from the start of infancy [...] from earliest youth.' ${ }^{21}$ Piccolomini invoked classical authorities in arguing that the shaping of the body and mind 'should be done together from infancy', beginning 'in the very cradle.'22 Matteo Palmieri, in his Della vita civile, echoed Quintilian's warnings about the earliest exposures of highly malleable babies and toddlers to outside influences. ${ }^{23}$ Dominici cautioned that a toddler's 'habits and desires' were established by the age of two to three, and that therefore 'what you want him to be when he is grown accustom him to as a child. ${ }^{24}$ These were not casual suggestions: medical understandings of the childish body made them imperative. The physician Girolamo Mercurio, in a widely read work of 1596, advised that due to an infant's receptiveness to both environmental and physiological factors parents ought to take particular care when choosing a

Although it was not widely read in the period, it provides valuable evidence of contemporary attitudes to children's spiritual education and home lives.

17 On the Aristotelian cognitive model and its cultural dominance see Clark S., Vanities of the Eye: Vision in Early Modern European Culture (Oxford: 2007) 14-20.

18 Vergerio 15.

19 Translated in Kallendorf, Humanist Educational Treatises 71. Hereafter 'Piccolomini'.

$20 \quad$ Vergerio 17.

21 Ibid., 14.

22 Piccolomini 83.

23 This treatise was written in 1429 and published in 1528.

24 Dominici, Regola 141. 
wet-nurse. ${ }^{25}$ The baby, he explained, would imbibe something of the nurse's nature along with her milk, and because infants absorbed knowledge from birth, the woman should be forbidden from speaking to her charge in dialect. These ideas were not new: in his De re uxoria of 1416 Francesco Barbaro similarly cautioned that parents should take special care that babies not absorb malign impressioni from their wet-nurses. ${ }^{26}$ From the moment it came into the world an infant was thought to be under constant assault from the species that surrounded, penetrated and ultimately shaped it. Without careful attention, the outcome of these processes could be ominous; parents who ignored this fact did so at risk of their children's souls.

\section{3}

\section{Pleasure and the Senses}

Other than by following the ubiquitous advice to set a good example and enforce a routine of daily prayer, how could adults mould impressionable children into good Christians? Fundamental to this endeavour was the conviction expressed by the humanist Marsilio Ficino that 'Since youth is inclined to pleasure, it is captivated by pleasure alone; it flees from strict teachers.'. ${ }^{27}$ Emphasis on the need for a child to enjoy her or his moral instruction appears with remarkable consistency in the writings of fifteenth and sixteenth century theologians, humanists, physicians and natural philosophers. It reveals a deeply rooted, shared understanding of childhood, based on the notion that the humours and physiology of the young inclined them naturally towards sensual pleasure. Cardinal Silvio Antoniano's 1584 treatise Dell'educazione Cristiana de' figliuoli, written at the behest of Carlo Borromeo, was one text among many that hammered home the point that children intuitively sought out sensory gratification. $^{28}$

This innate propensity for pleasure meant that anything causing fear, unhappiness or pain was likely to disturb and alienate a child. Drawing on the

25 Mercurio Girolamo, La commare o riccoglitrice (Venice, Ciotti: 1596), cap. xxv. Such advice was longstanding and was echoed by other authorities, such as Paolo da Certaldo and Bernardino da Siena. See Ross J.B., "The Middle-Class Child in Urban Italy" in deMause L. (ed.), The History of Childhood (New York: 1974) 185-186.

26 Barbaro Francesco, La elettion della moglie (Venice, Gabriele Giolito: 1548) 60.

27 Original in Sears J., Marsilio Ficino's Commentary on Plato's Symposium (Columbia: 1944) 118. Translated in Ficino Marsilio, Commentary on Plato's Symposium on Love, trans J. Sears (Dallas: 1985) 173 .

28 Antoniano Silvio, Dell'educazione cristiana dei figliuoli (Verona, Sebastiano dalle Donne: 1584). 
pedagogical inheritance of classical authorities, Erasmus recommended lenience and kindness over corporeal punishment, and Alberti, Battista Guarino and Piccolomini all cautioned against the negative and counter-productive effects of beating children. ${ }^{29}$ The physician Michele Savonarola, with reference to Avicenna, declared that fear would upset a child's humoural balance and endanger his health, and that moral instruction depended on loving encouragement. ${ }^{30}$ Vergerio concurred, stating that because the humoural composition of the young led them to 'follow their passions above all', a harsh approach 'saps intellectual energies and quenches the little fires that nature lights in children [...] and it is a good idea to give them their head to enjoy freedom and fun'. ${ }^{31}$

Yet it was widely acknowledged that the childish inclination to pleasure could all too easily lead to sin. The suggested remedy for this propensity was not denial of the sensual, but active attempts to channel it towards positive behaviours and tastes. Sense impressions that were received with delight, it was believed, would create the firmest imprints in youthful matter. What children enjoyed therefore had a profound effect on them, working to shape their minds, bodies and souls. There was no point trying to subvert or circumnavigate this fact; the spiritual education on the young had to be approached in light of it. Dominici recommended that parents follow the advice found in Saint Jerome's letter to Laeta on the education of her daughter, which advised: 'Offer prizes [...] and draw her onwards with little gifts such as children of her age delight in [...] You must not scold her if she is slow to learn but must employ praise to excite her mind [...] Above all you must take care not to make her lessons distasteful to her.' ${ }^{32}$ In line with this advice, Alberti noted that while little girls' domestic spaces ought to be 'dedicated to religion and chastity' they should nonetheless be comfortable and pleasant. ${ }^{33}$

It is within this context - of harnessing a child's inclination towards pleasure - that Dominici's oft-quoted passage on children's play should be

29 Erasmus D., The Education of a Christian Prince, ed. L. Jardine (Cambridge: 1997) 8; Alberti Leon Battista, I libri della famiglia, eds. R. Romano - A. Tenenti - F. Furlan (Turin: 1994) 81; Piccolomini 70-71; Guarino Battista, De ordine docendi et studendi (Ferrara, Andreas Belfortis: 1474), translated in Kallendorf, Humanist Educational Treatises 136. Hereafter 'Guarino'. This advice drew on classical precedent, for Quintilian, Plutarch and Aristotle had all recommended lenience when it came to children.

30 Savonarola Michele, Il trattato ginecologico-pediatrico in volgare: Ad mulieres ferrarienses, ed. L. Belloni (Milan: 1952) 192-195.

31 Vergerio 16.

32 Browning D. - Bunge M. (eds.), Children and Childhood in World Religions: Primary Sources and Texts (New Brunswick - London: 2009) 108.

33 Alberti Leon Battista, On the Art of Building in Ten Books, trans. J. Rykwer - N. Leach R. Tavernor, (London: 1988) 5:149. 
understood. Linking cognitive and spiritual development with humoural make-up, he advised that at an age when 'hot-bloodedness' prompted little boys to move, run and jump, and 'there is an abundance of humoural energy' parents should put a stop to dancing and play fighting. Instead they should:

Prudently endeavour to have them [...] play and amuse themselves so that they do not separate from God but unite with Him [...] make a little altar or two in the house [...] You can have three or four different coloured little vestments and he and the other children may be sacristans $[. .$.$] they can be occupied making garlands of flowers and plants,$ to crown Jesus with or to adorn the picture of the Virgin Mary, they can light and extinguish little candles and incense, keep clean, sweep, and prepare the altars [...] have a little bell and run to ring it at all hours [...] sing as well as they know how to, play at saying Mass, and be brought to the church sometimes and be shown how the real priests do it, that they may imitate them. ${ }^{34}$

The emphasis here is not just on play-acting, but on creating an environment rich in colour, fragrance, sound, light and sensory stimulation (through dressing-up, lighting incense, ringing bells, and the handling of flowers, wax and candles) that would seduce a hot-blooded, impressionable child into licit activities in which he would take real pleasure. Dominici was not alone in offering such advice. The late fifteenth-century Decor puellarum, attributed to Fra Giovanni di Dio da Venezia, likewise suggested that young girls ought to play at little altars. They too could engage in activities that enjoyably stimulated the senses, but that were adapted to be appropriate to their sex: producing 'beautiful' handmade decorations and 'delightfully adorning' an altar with 'beautiful images' ${ }^{35}$ These pastimes fulfilled the requirement that children's religious instruction be based in sensory pleasure and play, rather than dry instruction or admonition.

It is difficult to assess how commonplace such activities might have been in reality. It was reported (surely with an eye to shaping his hagiography) that Girolamo Savonarola had occupied himself with similar games as a child, and evidence from inventories confirms that some Renaissance homes contained child-size altars and their accoutrements. ${ }^{36}$ But for the majority of

34 Dominici, Regola 145-146.

35 Decor puellarum (Venice, Nicolas Jensen: 1471) 44v.

36 Pico della Mirandola Giovanni, Vita R.P. Hieronimi Savonarola (Paris, Sumptibus Ludovici Billaine: 1674) 6, cited in Klapisch-Zuber, Women, Family and Ritual 322. Musacchio J.M., 
parents - who were themselves busily occupied, whose children were expected to help around the house, and who could not afford to purchase an altarino for this kind of play - the advice proffered by these churchmen was of limited use. Crucially, nor did it provide much help with the imperative to commence shaping children in a desired form from the moment of birth, before they were old enough for such games. If character was fixed by the time a child began to speak, then alternative approaches were necessary.

\section{$4 \quad$ Art Theory}

Far more ubiquitous in Italian Renaissance homes than child-size altars were works of art. According to the dominant Aristotelian model of sensory perception, which privileged sight over the other senses, images accessed the soul with an immediacy that books and words lacked. ${ }^{37}$ While it was possible to focus on mental images during prayer, a painted or sculpted work was a far more stable and reliable aid. This was especially true for laypeople, particularly those with unformed, childish minds. These convictions underpinned the arguments of Catholic thinkers when Reformation criticisms prompted them to articulate clear defences of religious artworks. Gian Paolo Lomazzo asserted that paintings had greater spiritual potency than texts because they more effectively penetrated the intellective faculties and impressed themselves into the memory. ${ }^{38}$ Cardinal Gabriele Paleotti similarly explained that from contemplation of an image 'such strong impressions may be made on our fantasy $[\ldots]$ that those forms leave alterations and striking signs on the bodies of persons' and 'whatever we cogitate while studying images is painted right into the heart'. ${ }^{39}$ The potency of this process was attested to by cases such as that of 'a woman accused of adultery on account of having given birth to a darkskinned infant looking not at all like its father [...] [because] she had a similar image in her room', or 'a father who wanted handsome children, so he gave

Art, Marriage, and Family in the Florentine Renaissance Palace (New Haven: 2009) 213-214.

37 For a survey of early modern assertions of the superiority of sight over the other senses see Clark, Vanities of the Eye 9-13. This is not to deny the significance of the other senses to devotion, on which see de Boer W. - Gottler C. (eds), Religion and the Senses in Early Modern Europe, Intersections 26 (Leiden - Boston: 2012).

38 Lomazzo Gian Paolo, Trattato dell'arte della pittura (Milan, Paolo Gottardo Pontio: 1584) 2,6 .

39 Paleotti Gabriele, Discorso intorno alle immagini sacre e profane (Bologna, Alessandro Benacci: 1582). Translated in Paleotti Gabriele, Discourse on Sacred and Profane Images, trans. W. McCuaig (Los Angeles: 2012) 120; 119. 
his wife a picture of a beautiful, gentle boy so its figure would be imprinted in her imagination': ${ }^{40}$

Church authorities also emphasised the central role of pleasure in their defences of religious images. Spiritual improvement depended initially on a work's ability to captivate the attention, with Paleotti declaring that the artist's first duty was to 'supply delight' and only then 'to instruct, and to move the emotions of the observer'.41 He described 'the great sensual pleasure' that derived from contemplation of beauty, and argued that 'while literacy and knowledge of books can be acquired only with great effort, travail and expense, we are taught by images with the utmost sweetness and recreation'. It was precisely this pleasure in viewing that caused a picture to be firmly imprinted into the beholder, for 'with books [...] you may forget with great ease, whereas images sculpt what they teach you into the panels of memory so firmly they remain stamped there for many years.' ${ }^{42}$ When it came to religious instruction, then, 'what more expeditious or clear or helpful method could we possibly find than that of sacred images?'. ${ }^{3}$

The same concepts informed advice literature. A 1589 work, Nicolò Vito di Gozze's Governo della Famiglia, repeated the familiar assertions that the young were particularly susceptible to the indelible action of sense impressions, and that they were attracted to what pleased them. As a result, good parents had to shield their children from the sight of ugly and immoral things and, by implication, expose them to beautiful and edifying ones. ${ }^{44}$ The visual and aesthetic qualities of works of art were thus given special prominence in a discourse that had profound implications for the endeavour to shape the souls of the young. In the chapter titled 'Home training' which opens his text, Dominici states that his first rule for parents was 'to have in the home pictures of saintly children or young virgins, in which your children, still in swaddling clothes, can take delight and similarly be enraptured by acts and signs pleasing to childhood' [emphasis mine]. ${ }^{45}$ Particularly noteworthy in the light of the arguments that have been presented here thus far are his stress on delight, on the nature of the artwork as inherently 'pleasing to childhood' and on its affective power over the youngest members of the household.

\footnotetext{
$40 \quad$ Ibid., 121.

41 Ibid., 111. On the fundamental importance of pictures providing pleasure see also 87, 109, 235,278 .

42 Ibid., 115 .

43 Ibid.

44 Nicolò Vito di Gozze, Governo della famiglia (Venice, Aldus M: 1589) 80.

45 Dominici, Regola 131.
} 
Two further early modern suppositions are worth mentioning briefly before turning to more in-depth consideration of the relationship between children and religious images. The first is that pleasure in something would stimulate the desire to repeat it, thereby forming a habit; the second is that habitual, repeated actions created indelible memories which were central to the formation of character and soul.

Habitual action has a major role in treatises on child rearing. When Dominici cautioned that a toddler's 'habits and desires' were established by the age of two to three, and that if parents had not exercised a positive influence by this stage then it was too late, he did so in a chapter on habit. ${ }^{46}$ Repetition was considered fundamental to the formation and retention of memories, and for many early modern authors frequency of action is afforded greater significance than a child's comprehension. ${ }^{47}$ In a chapter of his treatise dedicated to the moral education of children the physician Michele Savonarola declared that a parent's single most important task was to develop a child's memory, and recommended that children be brought to church to absorb the services there before they could even talk. ${ }^{48}$

Habits imprinted the soul, as Aristotle and later Aquinas made clear; or, as Dominici put it, 'custom becomes nature. ${ }^{49}$ Parents who followed Guarino's advice in ensuring that their children's spiritual lessons were 'stamp[ed] [...] into memory so strongly that they can be expunged only with the greatest difficulty', that they were 'so fixed in their minds that no interval of time, no occupation - however varied or important - can eradicate them' could rest easy in the knowledge that they had fulfilled their duty. ${ }^{50}$ Relevant to this endeavour was the fact that the young were naturally inclined to repeat anything they found pleasurable. Habitual, enjoyable, quotidian domestic activities, which could commence from birth, would therefore form deep impressions in naturally malleable infants.

\footnotetext{
$46 \quad$ Ibid., 141.

47 Carruthers M., The Book of Memory: A Study of Memory in Medieval Culture (Cambridge New York: 2008); Yates F.A., The Art of Memory (London: 1966); Bolzoni L. - Erlindo V. Morelli M. (eds.), Memoria e memorie (Florence: 1998).

48 Savonarola, Ad mulieres ferrarienses 196-200.

49 Dominici, Regola 137.

50 Guarino 151, 140. For further statements on the importance of memory to a child's upbringing see also Vergerio 31; and Piccolomini 91, 111.
} 
A late fifteenth-century miracle story tells of a home in Lombardy which contained an image of the Madonna. ${ }^{51}$ In this house lived a fanciullo who was 'tanto piccolo', so that when he encountered the picture he saluted it by force of habit, rather than in comprehension of the significance of his actions. Nonetheless, when he fell into a river and was at risk of drowning, the very same Madonna appeared to him and saved him from danger. The tale communicates the extraordinary power of images, which made the divine manifest in people's lives and homes. But it also confirms the central role that works of art could play in inculcating habitual pious behaviour in little children, shaping them into good Catholics before they could even fully comprehend what this entailed.

Long before a child could speak the words of the Our Father, or kneel in prayer, she or he could look at an image. It has been established that in early modern thought the young were both exceptionally receptive to the action of sensory impressions and susceptible to pleasure, and that images were particularly well able to delight and penetrate the soul. The confluence of these ideas meant that a well-formed work of art could charm infants 'still in swaddling clothes', who did not need to comprehend what they saw for it to captivate them, stimulate repeated looking, and (due to the action of sense impressions on the child) shape their souls. These factors informed the advice of contemporaries such as Cardinal Silvio Antoniano, who explicitly stated that children would learn better from images than texts, in part because these pictures imprinted themselves forcefully into youthful memories. ${ }^{52}$ As a result, parents were advised to fill the home with religious works of art which, when encountered on a daily basis, were acknowledged to be perfect vehicles for Christian education. Contemporary recognition of this fact, it shall be argued, likely informed the production of images for domestic devotion that were particularly suited to little children.

Evidence from inventories makes clear that youngsters from elite households had devotional artworks in their chambers. In Florence in 1497, the room of the ten year old son of Giovanni di Francesco Tornabuoni was recorded to contain a Madonna and Child painting, a statuette of the Virgin and a small

$51 \quad$ Miracoli della gloriosa Vergine Maria historiati (Venice, Agostino Bindoni: 1551) cap. 35 . This collection was popular and was printed many times throughout the late fifteenth and sixteenth centuries.

52 Antoniano Silvio, Dell'educazione cristiana dei figliuoli (Verona, Sebastiano dalle Donne: 1584). 
tabernacle. ${ }^{53}$ An image of the Virgin with Christ and an angel, lit by a candleholder, was in the bedchamber of Guasparre Spinelli's eight-year-old son Tomaxo. The rooms of the ten-year-old son of Lorenzo Tornabuoni contained a gold-framed Madonna, an Annunciation scene and a crucifix. Other inventories reveal Marian artworks in the rooms of wet-nurses. ${ }^{54}$ Given that these documents record the possessions of their employers, and in the light of what has been argued thus far, it seems clear that these images were intended as much for the benefit of their charges as for the women themselves. However, passing references in the inventories of elite Florentine households provide only a partial and fleeting glimpse into the domestic visual culture of Italian infants. What of those lower down the social scale? Insight into the tastes and concerns of this section of society can be found not in written records, but in images themselves.

A huge number of small-scale religious works on panel were produced in this period, the majority of which were destined for people's homes. To take Milan as an example, around the year 1500 there were over 100 painters working in a city with a population of around 100,000. ${ }^{55} \mathrm{~A}$ handful of them, whose names are familiar today, were securing commissions for altarpieces, court portraits and paintings of mythological subjects for palazzi. But the majority were not. They were primarily occupied with painting the facades of houses, doing decorative work, and producing pictures for domestic devotion. The ratio of artists to inhabitants, as well as the high number of surviving paintings, gives a sense of just how substantial the trade in such works was in the sixteenth-century. By tracing the popularity of particular iconographies, it is possible to speculatively identify those that may have been made with children's souls in mind.

\section{Holy Babies}

A sheet of drawings by Leonardo, dating to when he was living in Milan in the last decade of the fifteenth century, depicts two toddlers embracing in a rocky landscape [Fig. 13.2]. These chubby figures appear in more or less the same form in a number of paintings that have been attributed to Lombard artists who worked closely alongside Leonardo, such as Marco d'Oggiono [Fig. 13.3].

53 Lydecker J.K., The Domestic Setting of Arts in Renaissance Florence, Ph.D. dissertation (John Hopkins University: 1987) 64, n. 84 .

54 For all these cases see Musacchio, Art, Marriage, and Family 210.

55 A document of 1511 was signed by 89 painters, and omits the names of several artists who are known to have been working in the city around this time. See Shell, Pittori in bottega 49-53. 


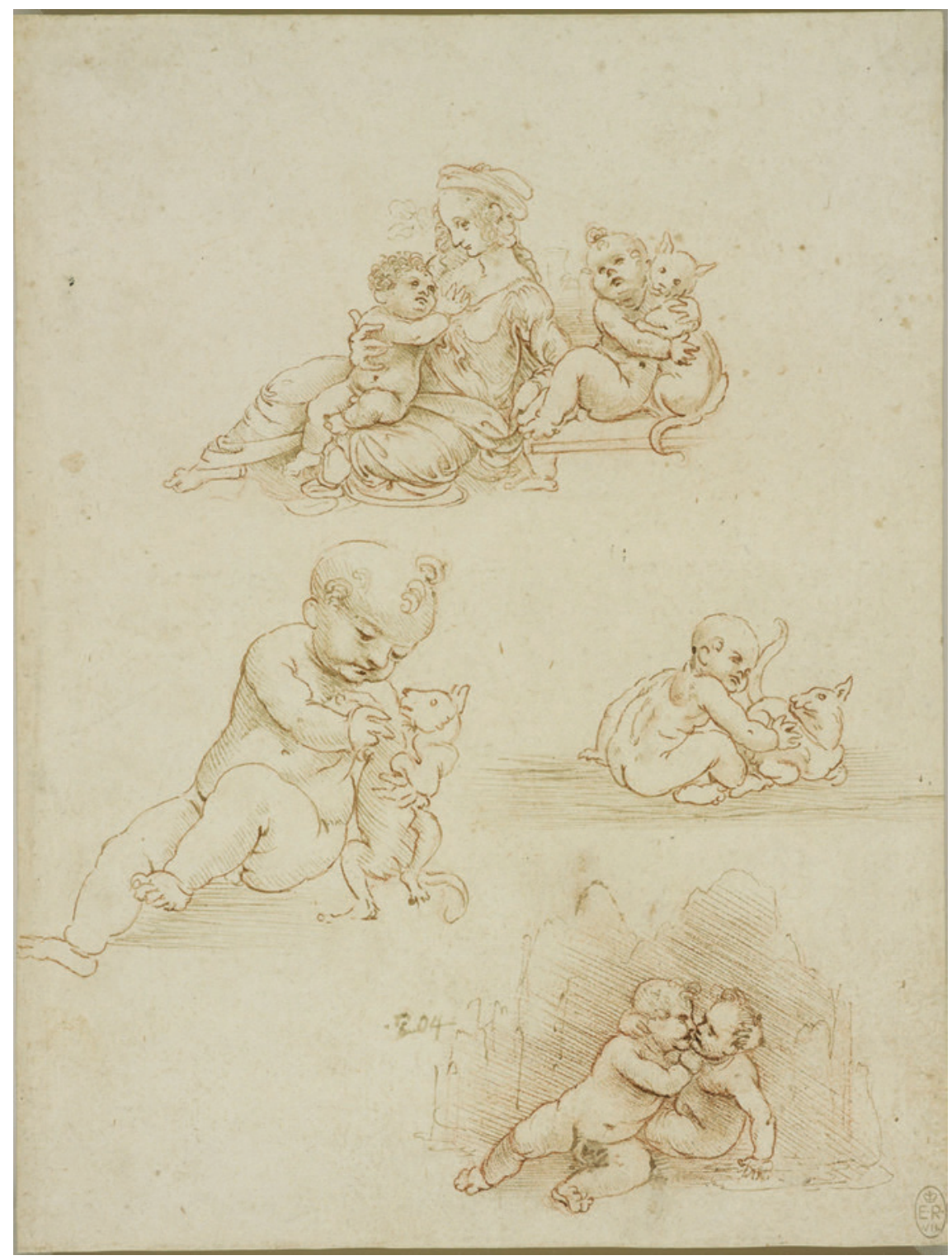

FIGURE 13.2 Leonardo da Vinci, "The Virgin and Child with a child and a cat, two studies of a child and a cat, and the Christ Child and infant Baptist embracing", ca. 1490-1500. Pen and ink over red chalk with touches of wash on paper, $20.2 \times 15.1 \mathrm{~cm}$. Royal Collection, Windsor ROYAL COLLECTION TRUST / (C) HER MAJESTY QUEEN ELIZABETH II 2017 


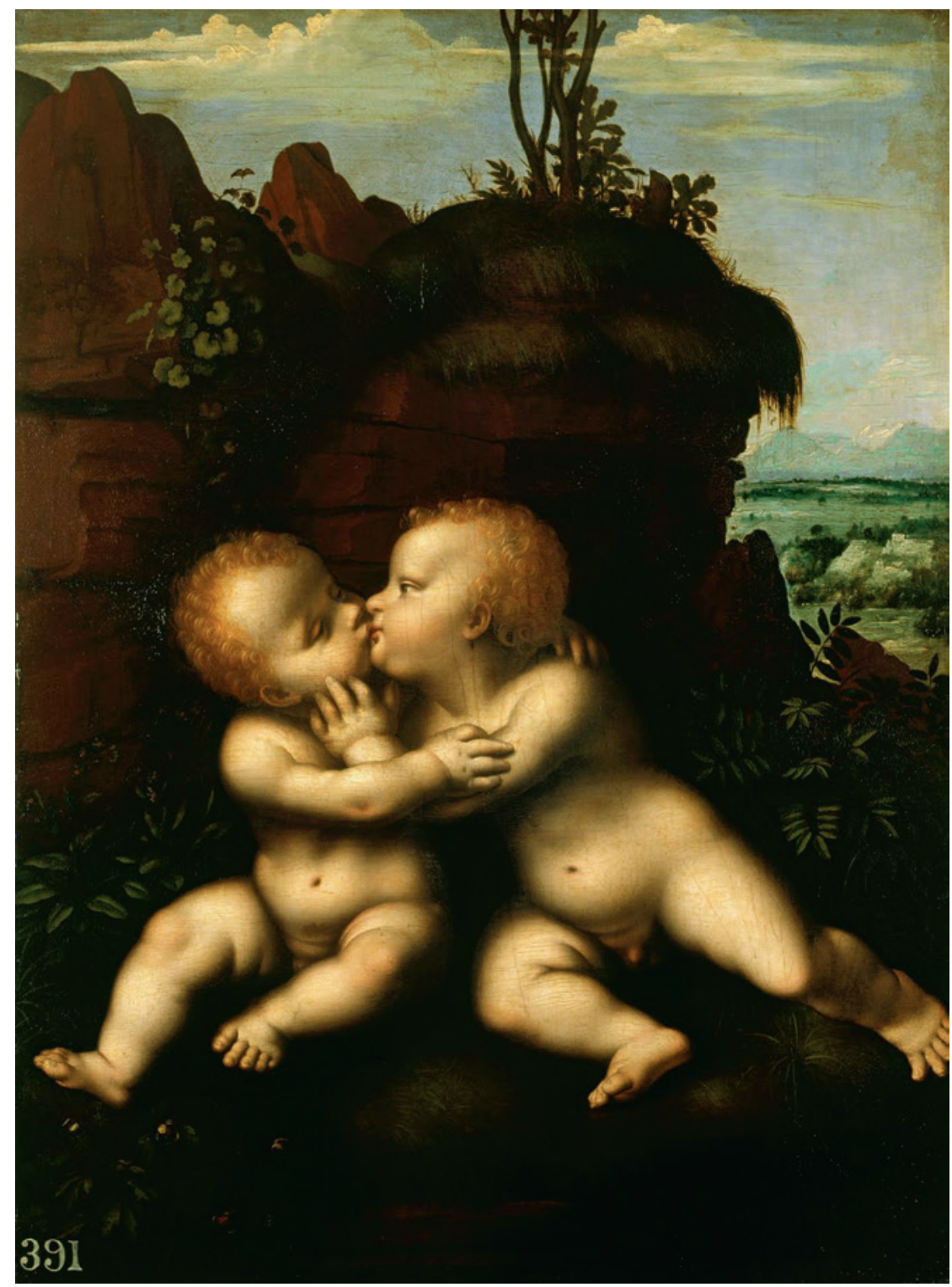

FIGURE 13.3 Marco d'Oggiono (?), "The Infant Christ and Saint John Embracing", ca. $1500-1530$. Oil on panel, $64.3 \times 48.1 \mathrm{~cm}$. Royal Collection, Windsor ROYAL COLLECTION TRUST / (C) HER MAJESTY QUEEN ELIZABETH II 2017 
They also feature in numerous pictures made well into the sixteenth century by those with less proximate links to the Florentine master, such as Bernardino dei Conti, Bernardino Luini and Giampietrino, and others whose names we do not know [Figs. 13.4 and 13.5].

A similar story of the diffusion of a particular iconography can be told of Leonardo's Virgin of the Rocks altarpiece. Originally painted for a confraternal chapel of the church of San Francesco Grande in Milan, it depicts the meeting in a rocky landscape of the Christ Child and his young cousin, Saint John the Baptist, accompanied by the Madonna and an angel. The entire composition

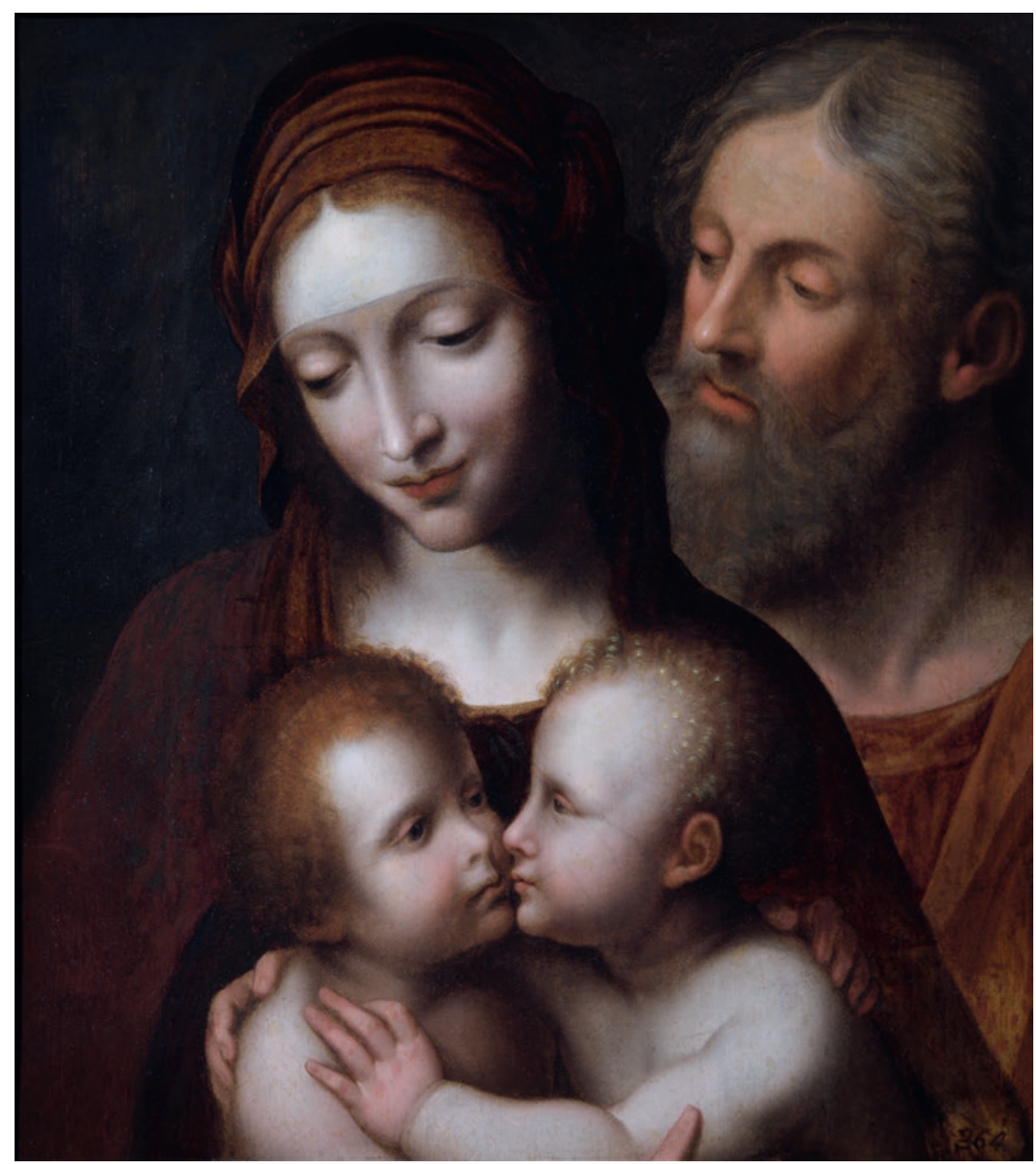

FIGURE 13.4 "Holy family with the infant St John", sixteenth century. Oil on panel, $51 \times$ $47 \mathrm{~cm}$. Wellington Collection, Apsley House, London

(C) HISTORIC ENGLAND ARCHIVE 


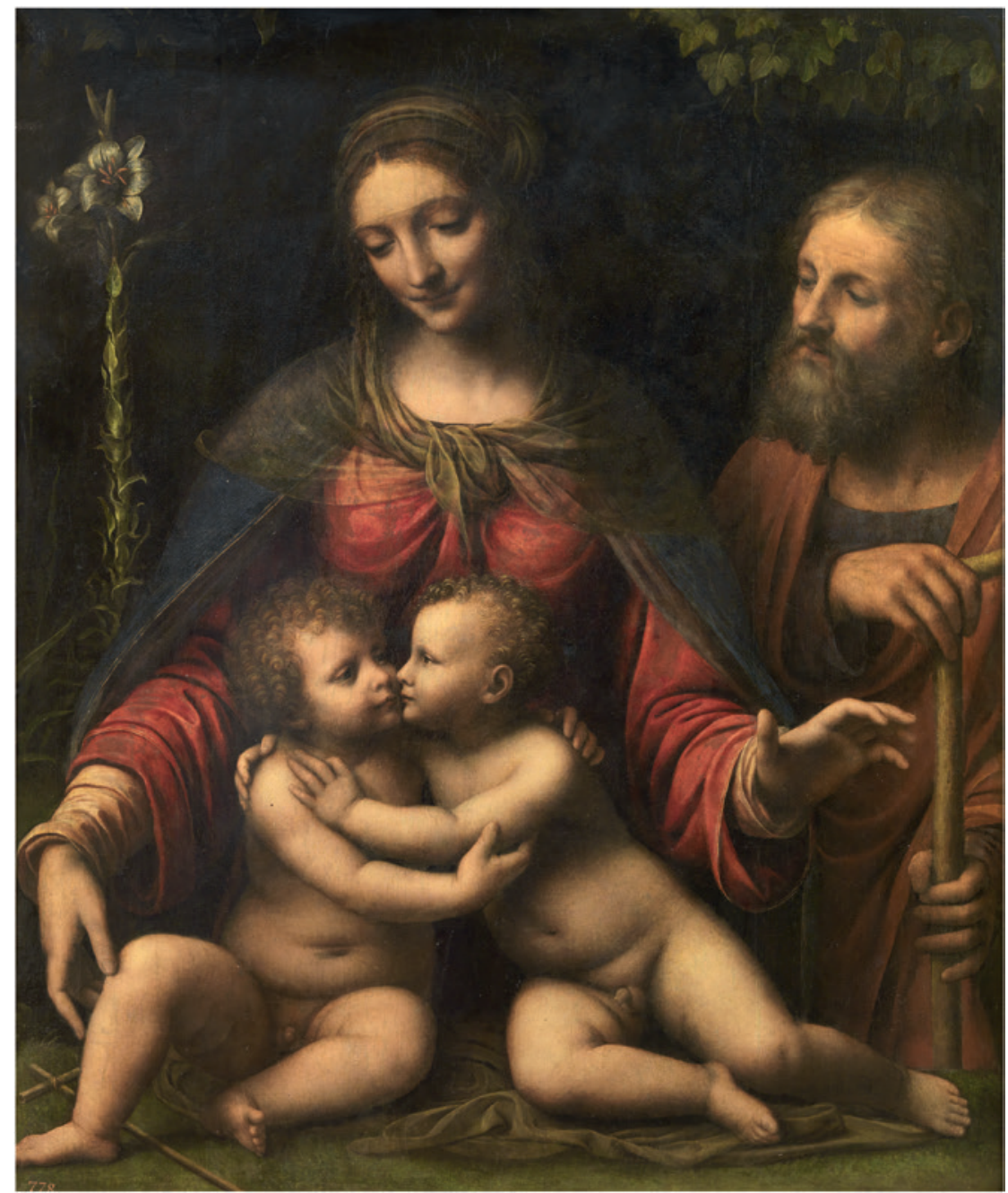

FIGURE 13.5 Bernardino Luini, "The Holy Family", first half of the sixteenth century. Oil on panel, $100 \times 84 \mathrm{~cm}$. Museo Nacional del Prado, Madrid

(C) MUSEO NACIONAL DEL PRADO

was copied frequently in works intended for private devotion - more than twenty small-scale copies of the painting are known today. ${ }^{56}$ In a substantial number of cases, though, the painting was reconfigured to place greater

$5^{6}$ Such works were usually produced without any documentation, so it is extremely rare to find archival traces of them. Occasionally it exists: in July 1522 Bernardino dei Conti agreed to produce a copy of the Virgin of the Rocks for Fra Arcangelo, a Franciscan living in 


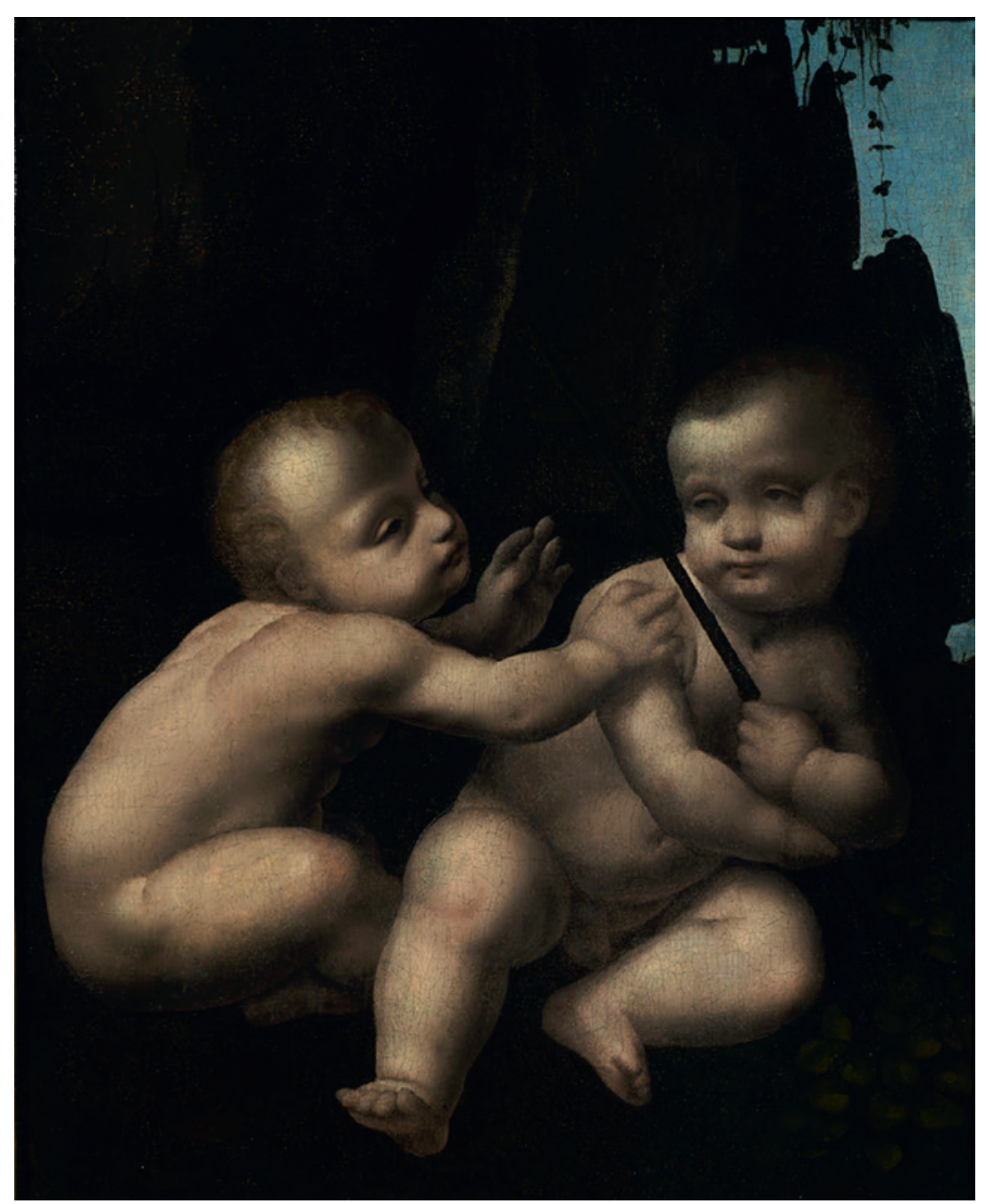

FIGURE 13.6 Attributed by Sotheby's to Marco d'Oggiono, "The Christ with the infant St. John the Baptist", early sixteenth century. Oil on panel, $43.8 \times 36.2 \mathrm{~cm}$. Private collection

(C) 2017 ART WORKS FINE ART PUBLISHING, LOS ANGELES

emphasis on the chubby children. Some works go so far as to isolate the infants and make them the entire focus of the composition [Fig. 13.6]. In others, elements from the Virgin of the Rocks were conflated with the imagery of the

the convent of San Francesco Grande, for the sum of 29 lire and eight soldi (this relatively high amount likely included the materials for the work), see Shell, Pittori in bottega 102. 
embracing babies [Fig. 13.7]. In a variety of ways, then, in large numbers these infants made their way into the homes of devotees across Northern Italy.

In many of these paintings, particularly those produced later on in the sixteenth century, any clear stylistic or iconographic relationship with Leonardo's work was more or less effaced [Fig. 13.8]. The enduring popularity of this imagery, isolated from its original contexts and repeated over decades of production, is clear evidence of a particular taste for religious pictures depicting holy babies. The majority of these pictures would have been sold as completed 'offthe-peg' works instead of being made to commission. Artists had to be confident that stock produced in this manner would sell: it often formed the bulk of their output, and, even for those enjoying notable success in their careers, such works were relied upon to supply a steady income in between commissions. What is more, there were other motifs in Leonardo's work that could just as easily have been repeated in this manner, but they were not. ${ }^{57}$ What, then, drove the market in these paintings?

This was a period of burgeoning interest in the details of Christ's childhood, no doubt partly stimulated by focus on the spiritual significance of the family and the moral status of children. While the Bible largely passes over the years between Christ's birth and his maturity, a number of popular religious texts were available that imaginatively recounted the Saviour's youth. The Meditationes vitae Christi, for instance, included pleasingly relatable details such as the little Christ helping Mary around the house with the chores. ${ }^{58}$ When read aloud to children stories like this provided an age-appropriate model of ideal behaviour.

Some of this literature alluded to a meeting between the infant Christ and John the Baptist, said to have occurred in the desert when the Holy Family was returning from their flight to Egypt. The encounter was described in the apocryphal Gospels, but was most widely disseminated in Italy via the earlyfourteenth-century Vita di San Giovanni Battista..$^{59}$ This related the childhood of Saint John, explaining that his deeply spiritual nature was apparent from birth. As a toddler he had retreated to his parents' garden to rejoice in God's

57 The imagery of the ideally beautiful saintly youth is one example. On this iconography see Corry M., "The Alluring Beauty of a Leonardesque Ideal”, Gender \& History 25, 3 (2013) $565-598$.

58 The Meditationes, which was written in the thirteenth century but attributed by contemporaries to Bonaventure, was one of the most popular religious texts of the day and was printed in numerous editions throughout the period.

59 This text was erroneously attributed to Domenico Cavalca. Another relevant text is Feo Belcari, La festa di san Giovanni quando fu visitato da christo nel diserto, produced in the second half of the fifteenth century. 


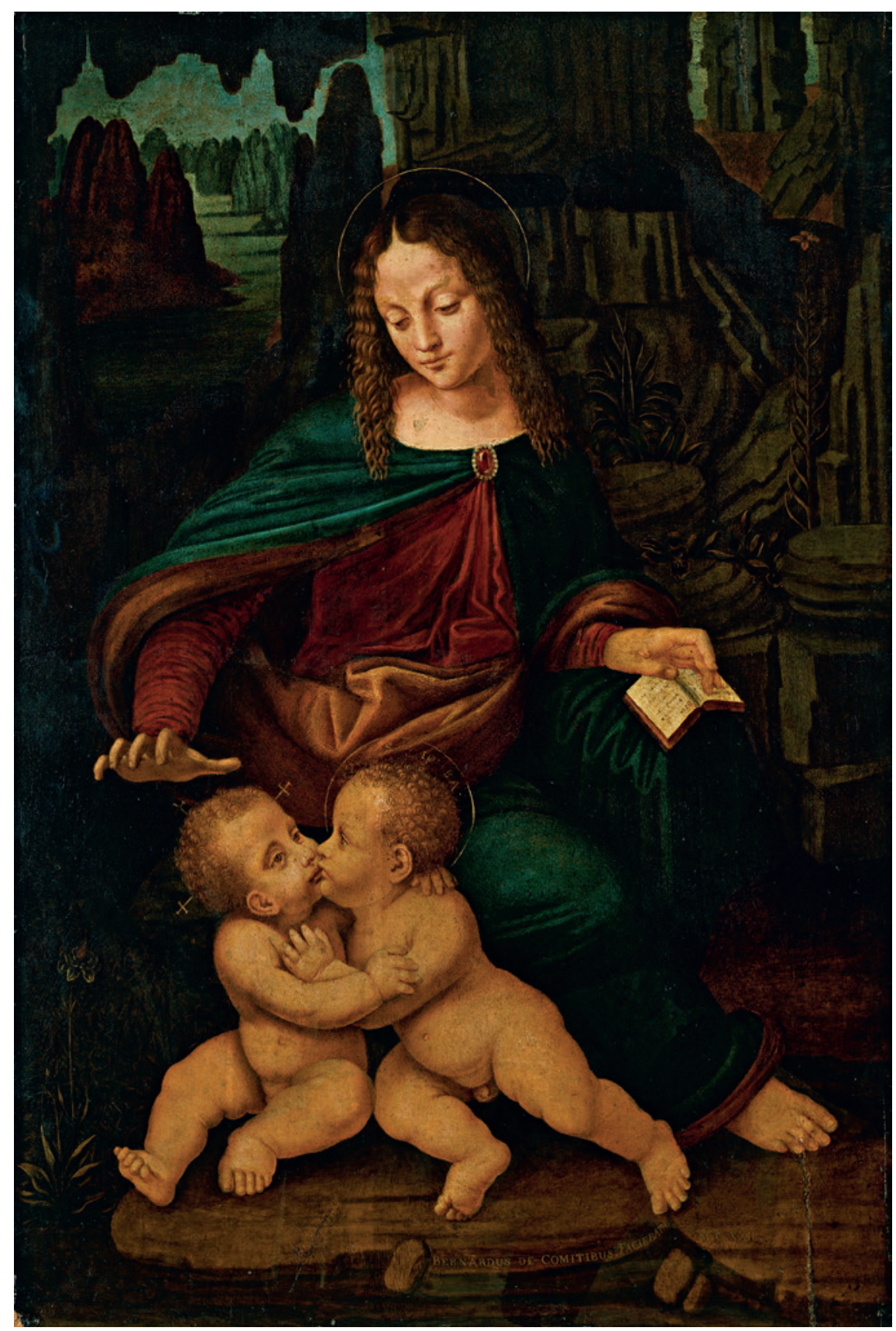

FIGURE 13.7 Bernardino dei Conti (?), "Madonna and Child with the Infant St John the Baptist”, 1496. Oil on panel, Pinacoteca di Brera, Milan

(C) MONDADORI PORTFOLIO/ELECTA/SERGIO ANELLI/ BRIDGEMAN IMAGES 


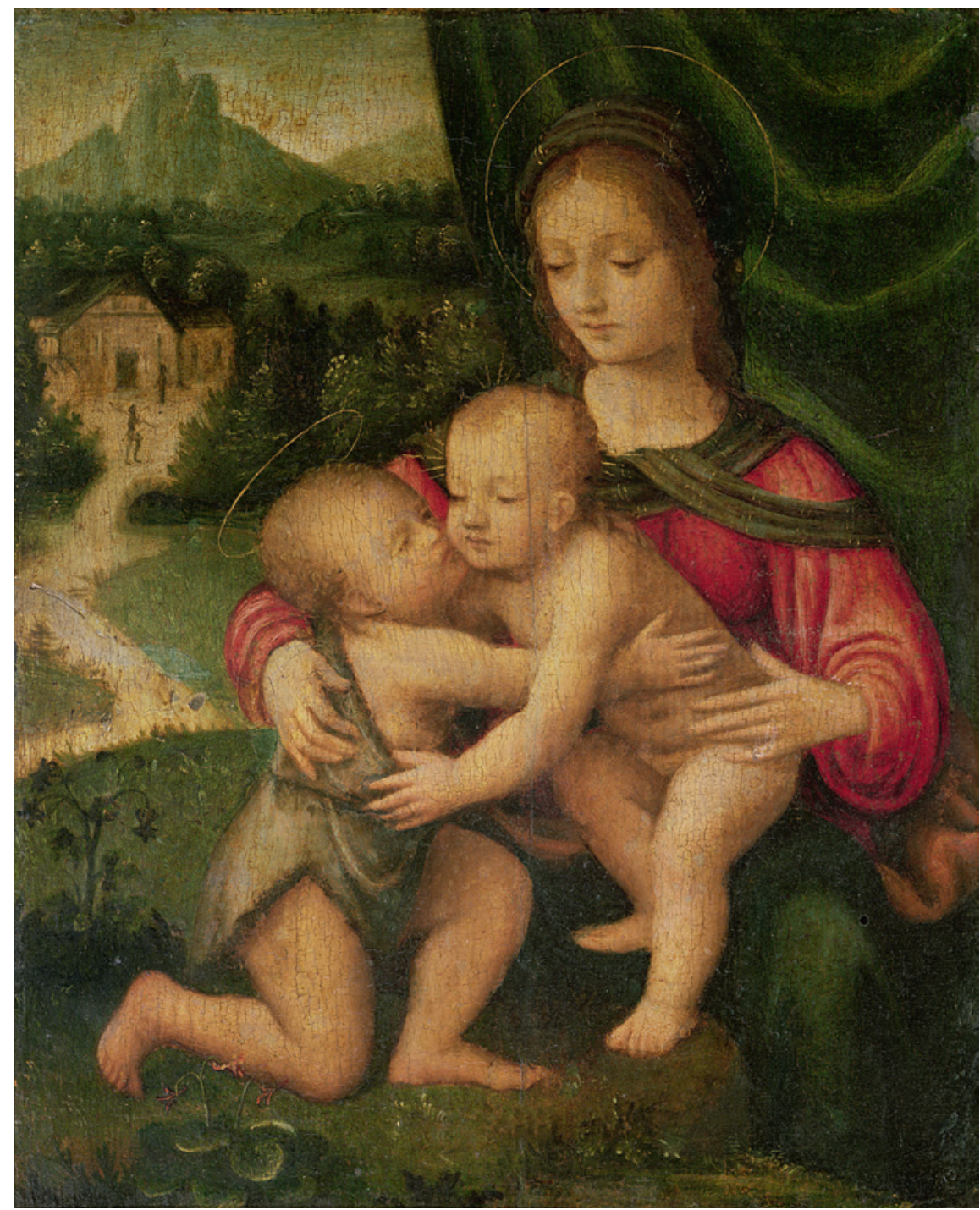

FIGURE 13.8 "Madonna and Child with St. John", ca. 1510. Oil on panel, $22.7 \times 18.5 \mathrm{~cm}$. Galleria dell' Accademia Carrara, Bergamo

(C) BRIDGEMAN IMAGES

creation, preferring meditative solitude to human company. In conformity with the ages of man, once he reached the age of seven he left his home to retreat into the wilderness. The author was careful to emphasise that despite John's extraordinary spiritual status his early years were still bounded by domesticity and respect for his parents' authority: he received religious teaching 
within the home at their behest, and sought their blessing before withdrawing into the desert. ${ }^{60}$

The Vita circulated widely in Florence, where it spawned imitators and informed artistic depictions of the child saint. ${ }^{61}$ These often had a civic dimension, for the Baptist was the city's patron saint. Clearly in Lombardy and beyond the iconography of the embracing children did not hold such significance. Nor was this civic aspect always the motivation for Florentine explorations of the theme. In 1458, Giuliano Quaratesi stated that he had recounted the story of the childhood meeting of the holy cousins because:

[...] from such a childish work that satisfies the souls of youths, they may gain such spiritual joy as comes from meditating and entering into the life of Christ and of his mother Our Lady, and if they find pleasure in thinking of the life of the saints in such childish ways, how much more will they think of the life of Christ which is perfection, and turning their minds to these small humble meditations they will learn how to enter and contemplate the great things of the saints and thus will begin to contemplate Christ $[\ldots . .]^{62}$

In other words, children had to commence their devotions by encountering holy figures in 'childish ways' and via 'childish works' - doing so provided them with pleasure and joy, and lay the groundwork for more mature and adult meditations.

The iconography of the embracing Christ and Baptist perfectly illustrated these concepts. In these paintings the viewer's attention is concentrated on the babies (when other figures are included they direct their gazes at the infants, who are always in the foreground). The children's interaction as they kiss and reach for one another with their chubby arms is active and loving, and in many of these images a playful aspect is emphasised, as the infant cousins gambol around the Virgin's skirts and amuse themselves with symbolically

60 Cavalca Domenico, Vite di alcuni santi scritte nel buon secolo della lingua Toscana, ed. D. Manni (Florence, Domenico Maria Manni: 1734) 202. Domenico Cavalca, Volgarizzamento delle vite de santi padri e di alcuni altri santi scritte nel buon secolo della lingua toscana (Milan: 1830-1858) vol. 4, 214-320.

61 Lavin M.A., "Giovannino Battista: A Study in Renaissance Religious Symbolism", The Art Bulletin 27, 2 (1955) 85-101.

62 Quaratesi Giuliano, Ms. Ricc. 1309, Biblioteca Riccardiana, 1r. Cited and trans. in Kent D., Cosimo de' Medici and the Florentine Renaissance, (New Haven: 2000) 97. 
significant flowers, lambs and birds [Fig. 13.9]. ${ }^{63}$ Love, childishness and playfulness were, of course, qualities that were understood to be particularly attractive and pleasing to the young.

The encounter between Christ and his cousin allowed these holy infants to express what Quaratesi defined as 'the ultimate love' for one another. This was stimulated by familial ties and the purity of their souls, but also by recognition, for the Baptist was the forerunner of Christ. This is significant, for implicit in Quaratesi's rationale for recounting the story of the meeting was the understanding that recognition would stimulate feelings of love. It was childishness - a likeness to themselves - that furnished the souls of the young with 'spiritual joy' and 'pleasure', just as it had for Christ and his cousin.

Beliefs inherited from the classical world declared that attraction was often based in recognition, that we are naturally inclined to love those in our own likeness. ${ }^{64}$ Paintings that confronted children with divine figures in whom they could perceive themselves therefore had a special charge. 'In this first mirror let your children be reflected, as they open their eyes' urged Dominici of devotional images in the home. ${ }^{65}$ A picture such as that in the Poldi Pezzoli collection of the baby Jesus (identifiable only by the unobtrusive light of his halo) would certainly have fulfilled this function for any infants in the household in which it was displayed [Fig. 13.10]. Dominici further instructed: 'let the child see himself mirrored in the Holy Baptist, clothed in camel skin, a little child who enters into the desert, plays with the birds, sucks the honeyed flowers, and sleeps on the ground. It will not be amiss if he should see Jesus and

63 See also The Virgin and Child with the Young St John the Baptist, The Ashmoleam Museum, inv. A79o; Giovan Battista della Cerva Novara, Madonna col Bambino e San Giovannino, private collection, sold by Sotheby's Milan 29th May 2007; Madonna and Child with the Infant Saint John, Museum of Fine Arts, Budapest, inv. 4238.

64 This was understood to be in anticipation of the shaping of the body and soul in the image of the familiar beloved. This concept, which depended on adherence to Aristotelian faculty psychology but also on the teachings of Plato and Plotinus, found expression in numerous intellectual discourses of the time. Ficino's De Amore explained that 'Likeness generates love', and that lovers 'celebrate those similar to themselves', Ficino, Commentary 53. Poetry of the period also explored how an exchange of souls would generate similarity between lovers and thus reinforce their bond, see Bolzoni L., Il cuore di cristallo. Ragionamenti d'amore, poesia e ritratto nel rinascimento (Turin: 2010).

65 Dominici, Regola 132. 


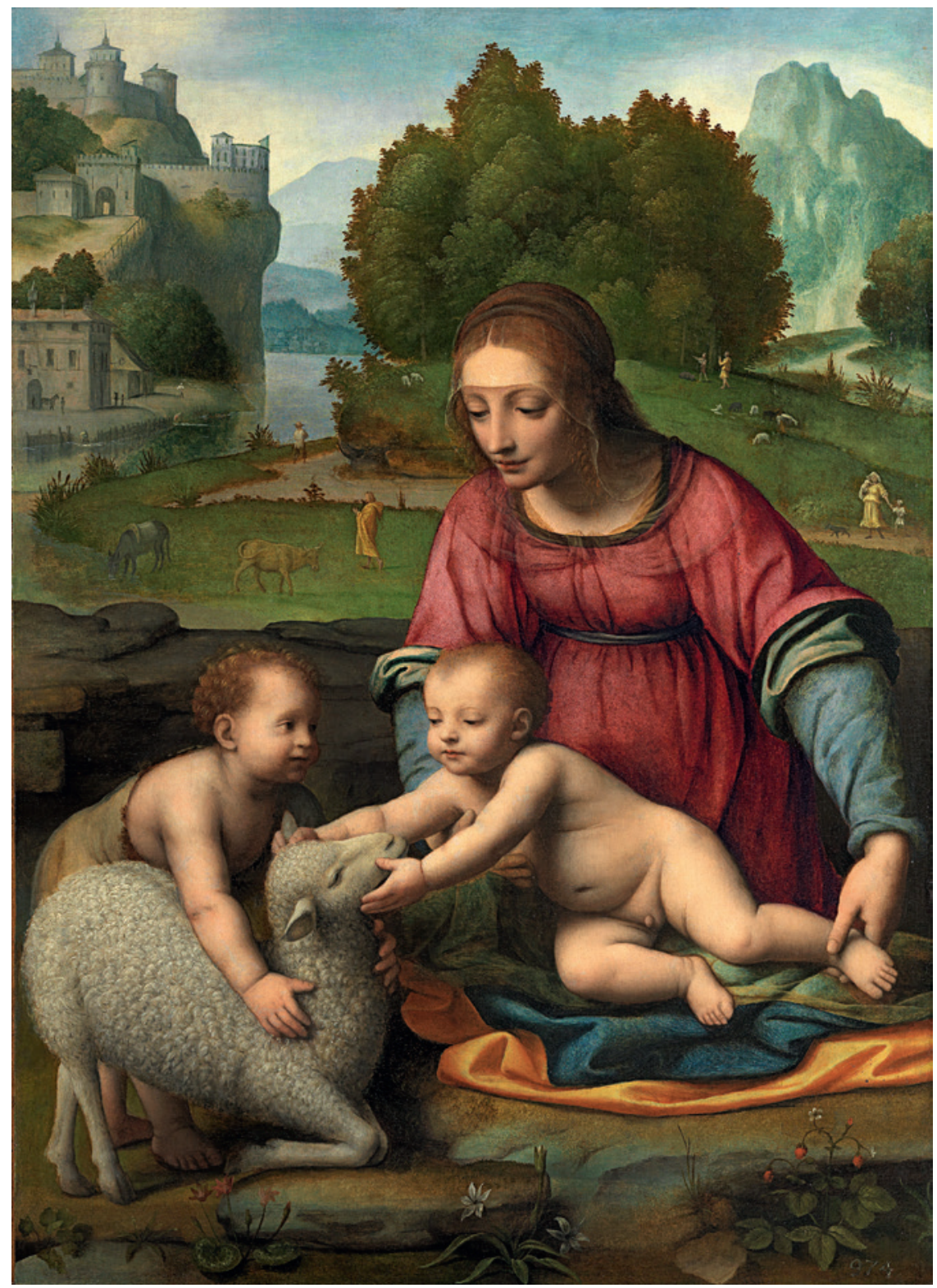

FIGURE 13.9 Bernardino Luini, "Virgin and Child with the Infant Saint John the Baptist", 1523-1525. Oil on canvas, $86 \times 60 \mathrm{~cm}$. Museo Nacional Thyssen-Bornemisza, Madrid

(C) FUNDACIÓN COLECCIÓN THYSEEN-BORNEMISZA 
the Baptist, Jesus and the little Evangelist pictured together'.66 A child at home in Lombardy in the early sixteenth century could gaze at the 'mirror' of The infant Christ and St John embracing and see nothing that visibly distinguished him from the depicted figures (they do not have haloes, nor the Baptist an animal-skin robe) [Fig. 13.3] ${ }^{67}$ A powerful affinity could thus exist between these painted infants and those who encountered them in their domestic environments from the moment that they 'opened their eyes'.

These ideas were not arcane or esoteric. Pedagogical texts consistently repeated that children learnt best by imitation, and that they were naturally drawn to emulate those who were similar. Vergerio declared that 'Young people should depend on companions ... in imitation of whom they may improve themselves'. ${ }^{68}$ This 'imitation' was effective because it was something in which the young 'take the greatest pleasure'.69 Guarino echoed that 'it is well to give the boys some companion [...] to kindle in them a spirit of emulation. ${ }^{70}$ The language of mirroring also appeared in contemporary discussions of how to shape the soul. Character flaws were revealed 'when a mirror is put before us', and youths were advised to 'often look at their own image in a mirror' in order to perceive their inner natures. ${ }^{71}$ More broadly, the ability to see oneself reflected in a holy figure had deep theological significance. Aquinas argued that spiritual meditation was 'the act of seeing God in oneself', in part because man was made in God's image. ${ }^{72}$ For Marsilio Ficino, the soul 'considers itself by contemplating the face of God [...] which shines within itself. ${ }^{73}$

Children, it has been established, were sensory beings. In spiritual terms, of course, this was potentially problematic. Those who were seduced by the material apparatus of the body and its sensations would not achieve salvation in the hereafter. But a different fate might await those who viewed an image of a holy baby from their cradles. What better 'companion' could an infant emulate than Christ himself? The playful and loving interaction depicted between him

66 Ibid., 131.

67 The same was not true of little girls, of course. The evidence of images and inventories suggests that parents were perhaps more willing to invest in the spiritual wellbeing of sons than daughters, or rather that the default position may have been to favour male children, and perceive them as the primary viewers of such works, whilst appreciating that daughters would also benefit from them.

68 Vergerio 11.

69 Ibid., 9 .

$70 \quad$ Guarino 136.

71 Vergerio $13,6$.

72 Thomas Aquinas, The Summa Theologica of St. Thomas Aquinas, trans. Fathers of the English Dominican Province (London: 1921) 1.3.5.

73 Ficino, Commentary 90. 


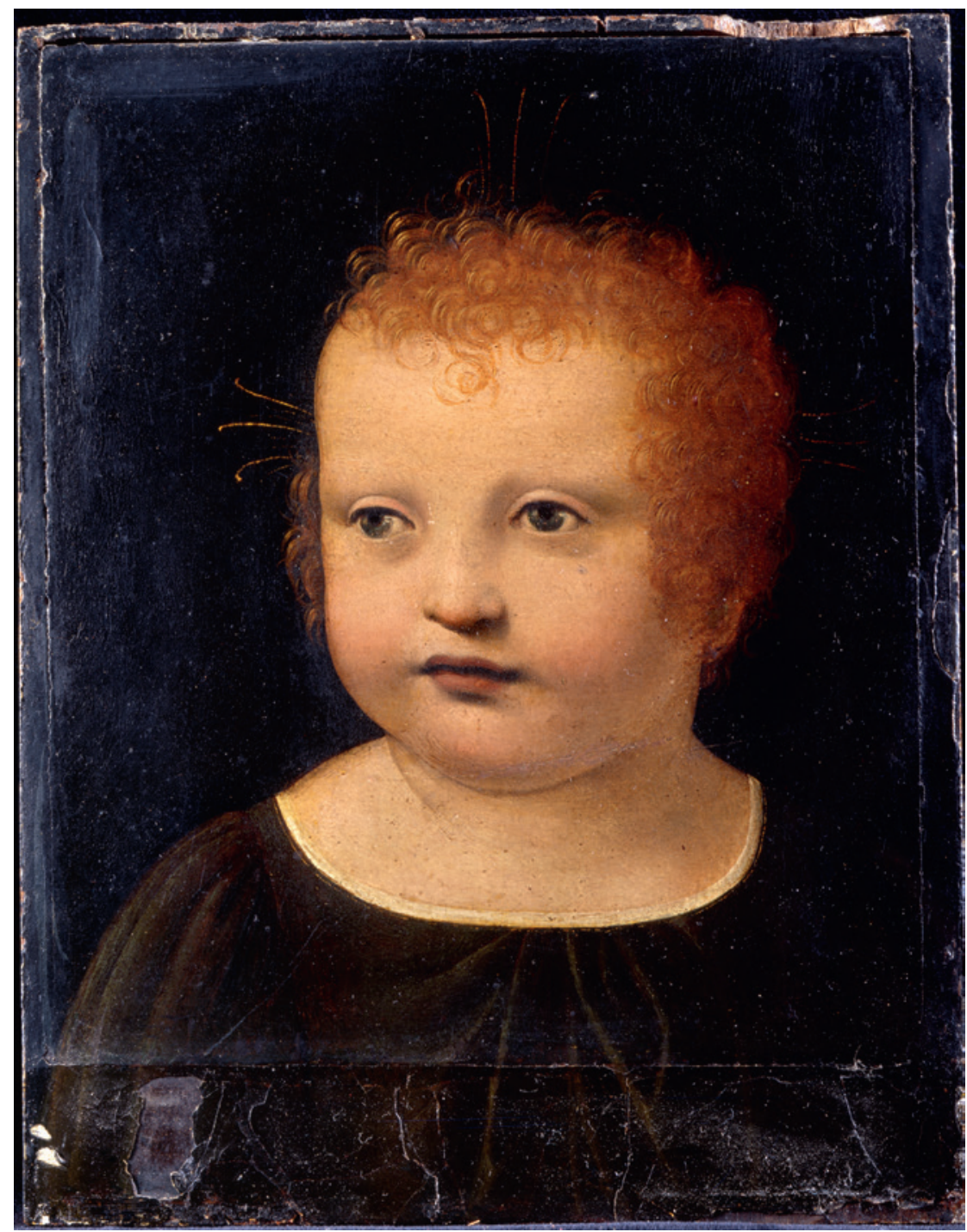

FIGURE 13.10 “The Christ Child", early sixteenth century. Oil on panel, $19.5 \times 15.5 \mathrm{~cm}$. Museo Poldi Pezzoli, Milan

(C) MUSEO POLDI PEZZOLI

and the Baptist would appeal to a toddler's most fundamental nature, prompting the desire to join them. What greater pleasure was there than this sense of proximity to the divine? Widely read devotional texts affirmed the extraordinary potency of this kind of experience. The Meditationes Vitae Christi advised that there was no 'greater sweetness' than to perceive Christ, and to converse 
with him as with a friend. The Vita Christi asserted that to imaginatively engage with holy figures resulted in 'greater pleasantness' and 'delight' than anything else. ${ }^{74}$ The heights of devotion were attained in this way, as a prayer in The Imitation of Christ confirmed: 'deepen your love in me, O Lord that I may learn in my inmost heart how sweet it is to love, to be dissolved, and to plunge myself into your love ... Let me love you more than myself, and myself only for you. ${ }^{75}$ These texts were aimed at adult devotees, who had to exercise their minds and imaginations to achieve these pleasures. But a similarly transformative experience was open to infants who, in their unthinking, unformed, sensory awareness, could delight in intimate daily encounters with painted holy babies in their homes.

\section{$9 \quad$ Conclusion}

In the curious painting with which I opened this investigation, the Baptist, bearing his identifying cruciform staff, stands before the Saviour, looking down at the little figure that he presents to him [Fig. 13.1]. This infant receives Christ's blessing in a similar manner to the many adults who are depicted in countless donor portraits in Renaissance art. But he cannot have commissioned the work himself. Whoever had this painting made was almost certainly not rich, but they were unquestionably concerned for the soul of this kneeling child. Perhaps the work commemorates the death of a much-loved infant, providing a focus for prayers that would speed the passage of his soul through purgatory. Maybe it is a votive image, made in thanks after the little supplicant survived illness or accident. But a third possibility exists: that this painting was commissioned by the child's parent in order that he might daily see himself interacting with divine figures, and receiving Christ's blessing in an act of ideal devotion. ${ }^{76}$ If this were the case, his malleable soul would be indelibly shaped by the pleasure he would take in the picture - in its calm landscape, lovely colours, relatable figures and, above all, in the appealing and spiritually edifying scene that it presented.

74 The Vita, written by Ludolph of Saxony in 1374, circulated widely across Europe in manuscript form before being printed. It was translated into Italian in 1570 .

75 Thomas à Kempis, The Imitation of Christ, trans. L. Sherley-Price (London: 1952) 98-99. There was of course a long tradition of similar expressions.

76 These possibilities are not mutually exclusive: an image that commemorated a dead child could still serve as a tool for the moral education of living infants in the household. 
In the climate of reform, exhortations to have religious images in the home increased, and their spiritual value was regularly articulated. ${ }^{77}$ Evidence from inventories confirms that children encountered paintings and sculptures of the youthful Christ and Baptist in domestic environments. ${ }^{78}$ Of course, only the wealthiest had chambers of their own, and the pictures under consideration here did not only hold meaning for the smallest members of a household. Their multivalence (a quality that must only have made them more marketable) is indicated by the conviction that images of lovely boys would assist in the conception of healthy male children. But their power did not cease once this had been achieved. Prescriptive written sources inform us of the expectations that weighed on adults with children in their care, but not how they responded to them. Works of art played a particular and crucial role in the endeavour to raise good Christians, and analysis of relatively cheap, devotional images that people had in their homes can shed new light on this matter. The numerous paintings of this type that have come down to us today indicate that the discourses outlined here powerfully shaped devotional culture and practice.

To some extent, the conclusions of a study such as this can only be speculative. Laypeople lower down the social scale did not usually record their experiences, hopes and desires in written form, and the motivations for purchasing a religious picture were numerous. What is nonetheless clear is that parents of all social levels in the early modern era loved their infants, feared for their souls, and felt social pressure to tend to them..$^{79}$ An ideal response to this imperative was indicated by Dominici, who instructed parents that a little boy should be able to 'delight in the companions which you had painted for him. ${ }^{80}$ It has been suggested here that numerous contemporaries may have heeded

77 See for instance Borromeo Carlo, Libretto de i ricordi al popolo della citta et diocese di Milano (Milan, Pacifico Pontio: 1578).

78 In 1498, Marcho d'Ugholino Bonsi had 2 gesso 'heads' in his bedchamber, of Christ and Baptist. There were four children under six living in the house at time. Another household with a painted head of St John the Baptist had six children living in it. See Musacchio, Art, Marriage, and Family 208. In the 1470s, Bartolomeo Sassetti's sons' rooms contained an image of the Virgin and Child, and one of the Virgin and Child with St John the Baptist - doubtless representing the cousins as young children. See Musacchio J.M., "The Madonna and Child, A Host of Saints, and Domestic Devotion in Renaissance Florence", in Neher G. - Shepherd R. (eds.), Revaluing Renaissance Art (Aldershot: 2000) 154-155.

The debate about whether parents in the pre-modern era were emotionally attached to their offspring was sparked by Philippe Ariès in his seminal Centuries of Childhood: A Social History of Family Life, trans. R. Baldick (New York: 1962). Serious challenges to Ariès have since been presented, see for instance Ozment S.E., Ancestors: The Loving Family in Old Europe (Cambridge, MA: 2001), and Haas, Renaissance Man. 
this advice to commission a devotional picture specifically for a child in their care, and that those who could not afford to do so might well have purchased a cheap panel with the same aim in mind. Images, such as those of embracing holy babies discussed here, were uniquely able to stimulate pleasure, love and recognition in infants, thereby shaping their souls and laying the groundwork for good spiritual habits that would last a lifetime.

\section{Bibliography}

Alberti Leon Battista, I libri della famiglia, eds. R. Romano - A. Tenenti - F. Furlan (Turin: 1994).

Antoniano Silvio, Dell'educazione cristiana de' figliuoli (Verona: Sebastiano dalle Donne: 1584).

Barbagli M., Sotto lo stesso tetto: mutamenti della famiglia in Italia dal XV al XX secolo (Bologna: 2000).

Black R., Humanism and Education in Medieval and Renaissance Italy: Tradition and Innovation in Latin Schools from the Twelfth to the Fifteenth Century (Cambridge: 2001).

Burrow J.A., The Ages of Man: A Study in Medieval Writing and Thought (New York: 1986).

Carruthers M., The Bookof Memory:A Study of Memory in Medieval Culture (CambridgeNew York: 2008).

Cavallo S. - Evangelisti S. (eds.), A Cultural History of Childhood and Family: The Early Modern Age (Oxford: 2000).

Clark S., Vanities of the Eye: Vision in Early Modern European Culture (Oxford: 2007).

de Boer W. - Gottler C. (eds.), Religion and the Senses in Early Modern Europe, Intersections 26 (Leiden - Boston: 2012).

Decor puellarum (Venice, Nicolas Jensen: 1471).

Delcorno C., "Maestri di preghiera per la pietà personale e di famiglia", Quaderni di storia religiosa 8, 2001 117-146.

Dominici Giovanni, Regola del governo di cura familiare, ed. D. Salvi (Florence: 1860).

Frigo D., Il padre di famiglia: governo della casa e governo civile nella tradizione dell"economica" tra Cinque e Seicento (Rome: 1985).

Grendler P.F., "The Schools of Christian Doctrine in Sixteenth-Century Italy", Church History 53, 3 (1984) 319-331.

Haas L., The Renaissance Man and His Children: Childbirth and Early Childhood in Florence, 1300-1600 (New York: 1998).

Kallendorf C. (ed. and trans.), Humanist Educational Treatises (Cambridge, Mass. London: 2002). 
King, M.L., "Concepts of Childhood: What We Know and Where We Might Go", Renaissance Quarterly 60.2 (2007) 371-407.

Klapisch-Zuber C., "Blood Parents and Milk Parents: Wet Nursing in Florence, 13001530", in Women, Family, and Ritual in Renaissance Italy, trans. L. Cochrane (Chicago: 1985).

Lomazzo Gian Paolo, Trattato dell'arte della pittura (Milan, Paolo Gottardo Pontio: 1584).

Musacchio J.M., Art, Marriage, and Family in the Florentine Renaissance Palace (New Haven: 2009).

Niccoli O., "Bambini in preghiera nell'Italia fra tardo medioevo e età tridentina", Quaderni di storia religiosa 8 (2001) 273-299.

Paleotti Gabriele, Discorso intorno alle immagini sacre e profane (Bologna, Alessandro Benacci: $15^{82}$ ).

Savonarola Michele, Il trattato ginecologico-pediatrico in volgare: Ad mulieres ferrarienses, ed. L. Belloni (Milan: 1952).

Sears E., The Ages of Man: Medieval Interpretations of the Life Cycle (Princeton: 1986).

Vergerio Pier Paolo, De ingenuis moribus ac liberalibus studiis liber (Milan, Filippo da Lavagna: 1474).

Zarri G. (ed.), Donna, disciplina, creanza cristiana dal XV al XVII secolo: studi e testi a stampa (Rome: 1996). 